\title{
Haematological and Serum Biochemical Profile of Growing Yankasa Ram Lambs Fed Diets Containing Graded Levels of Sesame Residue
}

\author{
Y. Garba, and E. A. Adeola
}

\begin{abstract}
An experiment was carried out to test the effect of Sesame residue (SR) inclusion in the diets of growing Yankasa ram lambs on haematological and serum biochemical parameters. Twelve (12) Yankasa ram lambs with initial body weight of $20.08 \pm 3.08 \mathrm{~kg}$ were allotted to three dietary treatments containing 0,20 and $30 \% \mathrm{SR}$ ( $\mathrm{A}, \mathrm{B}$ and $\mathrm{C}$ ). A completely randomized design was used for the study which lasted twelve (12) weeks. The haemetology results revealed that the white blood cells $(12.85-16.85109 / \mathrm{L})$, red blood cells $(1.49$ 2.04 1012/L), haemoglobin, mean corpuscular haemoglobin concentration (MCHC), mean corpuscular haemoglobin (MCH) (39.85-48.00 pg), mean corpuscular volume (MCV) and lymphocytes differed significantly $(P<0.05)$ among the treatments. Lambs fed 30\% SR had the highest MCV, MCH, MCHC and lymphocyte values. Serum biochemical analysis results revealed that lambs fed $20 \%$ and $30 \%$ SR had higher alkaline phosphatase, total protein and globulin values than lambs fed 0\%SR. However, SR inclusion in the diets did not affect calcium and phosphorus levels of the lambs. In conclusion, including sesame residue at $30 \%$ in the diets of growing Yankasa ram lambs had no observable adverse effect on haematological and serum biochemical parameters.
\end{abstract}

Index Terms - Haematology, Lamb, Serum Biochemistry, Sesame residue.

\section{INTRODUCTION}

Scarcity of forage resources during the dry season in semi-arid Nigeria poses an enormous challenge to small ruminant fattening programme in the region. Most ruminant farmers, usually smallholder in scale, rely solely on lowquality forages and crop residues in feeding their animals [1]. Some countries utilize sesame hulls ( $\mathrm{SH})$ for livestock feeding. However, published results examining the effect of dietary SH on farm animals' performance are very limited [2], [3].

Conducting blood analysis on animals after feeding trials is a readily available and quick means for evaluating clinical and nutritional status [4]. Animal scientists monitor and assess the nutritional and health status of animals by carrying out haematology and blood chemistry, which give reliable results [5]. Hence, this experiment was carried out to test the effects of including sesame residue in the diets of growing Yankasa ram lambs on blood metabolites.

Published on October 20, 2020.

Y. Garba, Bayero University, Kano, Nigeria.

(e-mail: ygarba.cda ${ }^{@}$ buk.edu.ng)

E. A. Adeola, Bayero University, Kano, Nigeria

(corresponding e-mail: emmayem.dtb@gmail.com)

\section{MATERIALS AND METHODS}

\section{A. Animal Care}

The experimental procedure was certified by the Bayero University, Kano, Animal research ethics committee and was carried out in line with standard procedures.

\section{B. Experimental Site}

The experiment was carried out on the Experimental Farm of the Centre for Dryland Agriculture, Bayero University, Kano (GPS Coordinates: N11 ${ }^{\circ} 86.155^{\prime}$, E $\left.8^{\circ} 98.955^{\prime}\right)$. Kano has two distinct seasons: Wet season which occur between May and September, and dry season which occur between October and April. The annual rainfall of the city ranges from 787 to $960 \mathrm{~mm}$ while the mean daily temperature varies between $30{ }^{\circ} \mathrm{C}$ to $33^{\circ} \mathrm{C}[6]$.

\section{Management of Animals}

Twelve (12) growing Yankasa ram lambs with initial body weight (BW) of $20.08 \pm 3.08 \mathrm{~kg}$ were used in the experiment. The lambs were purchased from Rimin-gado livestock market, Kano state. The lambs were drenched against internal parasites using Albendazole, which is a broad spectrum anthelmintic, at $1 \mathrm{ml}$ per $50 \mathrm{~kg}$ body weight. The lambs were ear-tagged and allocated to the three experimental treatments.

\section{Experimental Design and Diets}

A Completely Randomized Design (CRD) was used for the study where twelve ram lambs served as experimental units with each lamb serving as a replicate for the three treatment groups. Three experimental diets containing $0 \%$ (control diet), 20\%, and 30\% inclusion levels of sesame residues were prepared and designated them as $\mathrm{A}, \mathrm{B}$ and $\mathrm{C}$ (Table 1). The feed ingredients used were sesame residue, wheat offal, cowpea husk, cottonseed cake, rice mill waste, groundnut hay, salt and limestone, $\mathrm{h}$ purchased all the feed ingredients from Abuja livestock feed market in Kano.

\section{E. Blood Sampling}

Blood samples with or without anti-coagulant Ethylenediaminetetraacetic acid (EDTA) were obtained from the jugular vein of two lambs per treatment at the 63rd day of the study in the morning using a 5-ml syringe. Blood samples collected with EDTA were used for haematological analyses, while those collected without anti-coagulant were allowed to clot and the serum was separated by centrifugation for biochemical analyses. 
TABLE 1: GROSS COMPOSITION (\%) OF EXPERIMENTAL DIETS CONTAINING GRADED LEVELS OF SESAME RESIDUE FED TO GROWING YANKASA RAM

\begin{tabular}{|c|c|c|c|}
\hline \multicolumn{4}{|c|}{ LAMBS } \\
\hline Feed Ingredients & A $(0 \%)$ & B $(20 \%)$ & $\mathrm{C}(30 \%)$ \\
\hline Sesame residue & 0 & 20 & 30 \\
\hline Groundnut hay & 20 & 20 & 20 \\
\hline Wheat offal & 30 & 15 & 10 \\
\hline Cowpea husk & 14 & 14 & 14 \\
\hline Cotton seed cake & 20 & 10 & 5 \\
\hline Rice mill waste & 15 & 20 & 20 \\
\hline Common salt & 0.5 & 0.5 & 0.5 \\
\hline Limestone & 0.5 & 0.5 & 0.5 \\
\hline Total & 100 & 100 & 100 \\
\hline Calculated CP (\%) & 15.45 & 15.46 & 15.56 \\
\hline Calculated $\mathrm{E}(\mathrm{kcal} / \mathrm{kg})$ & 2560 & 2680 & 2750 \\
\hline
\end{tabular}

$\mathrm{A}=0 \%$ sesame residue (control), $\mathrm{B}=20 \%$ sesame residue, $\mathrm{C}=30 \%$ sesame residue, $\mathrm{CP}=$ crude protein, $\mathrm{E}=$ energy.

\section{F. Analytical Techniques}

Haematocrit, red blood cell, haemoglobin, white blood cell, and lymphocytes were measured according to Coles [7]. The mean corpuscular haemoglobin concentration (MCHC), mean corpuscular haemoglobin $(\mathrm{MCH})$, and mean corpuscular volume (MCV) were calculated as described by Aiello [8]. Alkaline phosphatase (ALP), aspartate aminotransferase (AST), and alanine aminotransferase (ALT) were determined using the spectrophotometric method [9]. Serum total protein (TP) was estimated using the Biuret method [10] while albumin (ALB) was determined according to Bromo Cresol green (BCG) method [11].

\section{G. Statistical Analysis}

All data were subjected to Analysis of Variance (ANOVA) using general linear model procedure in JMP [12] at 5\% significance level $(\mathrm{P}<0.05)$.

\section{RESUlTS AND DISCUSSION}

The haematological responses of the growing Yankasa ram lambs fed diets containing graded levels of sesame residue are shown in Table 2 . The results showed that all the haematological parameters investigated differed significantly $(\mathrm{P}<0.05)$ among the experimental treatments. The red blood cells values (1.49-2.77 1012/L) obtained in the present study were lower than the range $(9-11$ x $106 \mu \mathrm{l})$ recommended by Campbell et al [13] for sheep. However, the haemoglobin values obtained in this study (7.00 $8.80 \mathrm{~g} / \mathrm{dl}$ ) were close to the standard range of $8-16 \mathrm{~g} / \mathrm{dl}$ for sheep [14]. This revealed that oxygen and carbon dioxide carrying capacity of the lambs were in excellent condition. The high-quality protein of the experimental diets could have contributed to the haemoglobin values recorded in this study [15].

The values obtained for white blood cell of the lambs $(12.85-30.80 \mathrm{~g} / \mathrm{dl})$ were within the reference range of 9$31 \times 103 / \mathrm{mm} 3$ [16] for healthy sheep. Decreased white blood cell below the normal range show allergic conditions, anaphylactic shock [17] and certain parasitism or presence of a foreign body in circulating system [18]. Haematocrit values recorded from the experiment $(24.50 \%, 25.85 \%$ and
$23.25 \%)$ differed significantly $(\mathrm{P}<0.05)$. This showed that inclusion of sesame residue in the diets of lambs had an influence on their haematocrit level. However, the values obtained indicated that the dietary treatments met the nutritional requirements of the lambs [19]. The values recorded in this study were comparable to the values $(21.1-$ 29.4\%) reported by Bello and Tsado [15]. Lymphocytes values increased across dietary treatments. The Lymphocytes value (56.60-64.20\%) obtained in this study were within the reference range of 40-70\% [14] for healthy sheep. Mean corpuscular haemoglobin and mean corpuscular haemoglobin concentration are indicators of blood level conditions [20]. The higher values obtained in this study revealed that the experimental lambs were not anaemic.

The result of the serum biochemical parameters of growing Yankasa ram lambs fed diets containing graded levels of sesame residue is presented in Table 3. The values of total protein (TP), alkaline phosphatase (ALP), aspartate aminotransferase (AST) and globulin differed significantly $(\mathrm{P}<0.05)$ among dietary treatments. The values obtained for $\mathrm{TP}$ of the lambs ranged from $77.50 \mathrm{~g} / \mathrm{L}$ to $86.50 \mathrm{~g} / \mathrm{L}$. The values were highest in lambs fed $20 \%$ SR, while the lowest values were obtained from lambs placed on the control diet. However, the TP values were within the normal range for sheep [21]. The high TP values indicated an efficient protein synthesis [15]. ALP values recorded from the experiment ranged from $15.50 \mu / \mathrm{L}$ to $18.50 \mu / \mathrm{L}$. ALP values increased with an increasing level of sesame residue in the diets of the lambs. The significantly $(\mathrm{P}<0.05)$ different ALP values could be as a result of varying dietary phosphorus in the feed or its utilization as affected by phytate content of sesame residue. The globulin values of lambs fed diet containing sesame residue were significantly higher than the control group. The values obtained ranged from 36.50 to $54.50 \mathrm{~g} / \mathrm{L}$ which were similar to the values $(3.95-4.95 \mathrm{~g} / \mathrm{dl})$ reported by Garba and Abubakar [22]. The values obtained in this study implied good immune response of the lambs which might be due to normal water phase proteins and/or immunoglobins levels [23]

The values of phosphorus and calcium among dietary treatments did not differ significantly, and this showed that including sesame residue had no influence on the serum biochemical parameters. The albumin values obtained in this study (35-41 g/L) were higher than the range of 29-33 g/L reported by Njidda et al [24]. The total protein and albumin are indicators of the total protein reserve in an animal body [25]. Also, albumin concentration is an indicator of liver function [26]. The result obtained in this study suggested that sesame residue did not affect the functioning of the liver negatively, since albumin is synthesized mainly by the liver. The creatinine values obtained in this study (111.50$113.00 \mu \mathrm{mol} / \mathrm{L}$ ) were also higher than $87.50-100.00 \mathrm{mmol} / \mathrm{l}$ reported by Garba and Abubakar [22]. Inefficient metabolism of amino acid and protein increases creatinine level, and could result to cardiac defect and renal malfunction [27]. However, the urea values obtained in this study $(11.50-12.15 \mathrm{mmol} / \mathrm{L})$ were within the range of 8 $20 \mathrm{mg} / \mathrm{dl}$ reported by Banerjee [28]. The values recorded in this study implied that the dietary treatments supplied sufficient protein to the lambs [19]. The ALT values 
obtained in this study $(4.50-6.50 \mu / \mathrm{L})$ were higher than

32.00IU/L reported by Njidda et al [24].

TABLE 2: HAEMATOLOGICAL RESPONSES OF GROWING YANKASA RAM LAMBS FED DIETS CONTAINING GRADED LEVELS OF SESAME RESIDUE

\begin{tabular}{lcccc}
\hline \multirow{2}{*}{ PARAMETERS } & \multicolumn{3}{c}{ TREATMENTS } & SEM \\
\cline { 2 - 4 } & A $(0 \%)$ & B $(20 \%)$ & C $(30 \%)$ & 0.24 \\
White Blood Cell $\left(10^{9} / \mathrm{L}\right)$ & $16.85^{\mathrm{b}}$ & $30.80^{\mathrm{a}}$ & $12.85^{\mathrm{c}}$ & 0.14 \\
Red Blood Cell $\left(10^{12} / \mathrm{L}\right)$ & $2.04^{\mathrm{ab}}$ & $2.77^{\mathrm{a}}$ & $1.49^{\mathrm{c}}$ & 1.12 \\
Haematocrit $(\%)$ & $24.50^{\mathrm{ab}}$ & $25.85^{\mathrm{a}}$ & $23.25^{\mathrm{b}}$ & 0.14 \\
Haemoglobin $(\mathrm{g} / \mathrm{dl})$ & $7.95^{\mathrm{a}}$ & $8.80^{\mathrm{a}}$ & $7.00^{\mathrm{b}}$ & 0.52 \\
Mean Corpuscular Volume (fl) & $104.05^{\mathrm{ab}}$ & $101.00^{\mathrm{b}}$ & $105.80^{\mathrm{a}}$ & 0.27 \\
Mean Corpuscular Haemoglobin (pg) & $39.85^{\mathrm{b}}$ & $35.70^{\mathrm{c}}$ & $48.00^{\mathrm{a}}$ & \\
Mean Corpuscular Haemoglobin & $39.95^{\mathrm{b}}$ & $35.90^{\mathrm{c}}$ & $45.50^{\mathrm{a}}$ & 0.12 \\
Concentration $(\mathrm{g} / \mathrm{dl})$ & $56.60^{\mathrm{b}}$ & $58.50^{\mathrm{b}}$ & $64.20^{\mathrm{a}}$ & 0.41 \\
Lymphocyte $(\%)$ & & & & \\
\hline
\end{tabular}

$\mathrm{a}, \mathrm{b}, \mathrm{c}$, means in the same row with different superscripts are significantly different $(\mathrm{P}<0.05)$.

$\mathrm{A}=0 \%$ sesame residue (control), $\mathrm{B}=20 \%$ sesame residue, $\mathrm{C}=30 \%$ sesame residue, $\mathrm{SEM}=\mathrm{Standard}$ Error of Mean.

TABLE 3: SERUM BIOCHEMICAL PARAMETERS OF GROWING YANKASA RAM LAMBS FED DIETS CONTAINING GRADED LEVELS OF SESAME RESIDUE

\begin{tabular}{|c|c|c|c|c|}
\hline \multirow{2}{*}{ PARAMETERS } & \multicolumn{3}{|c|}{ TREATMENTS } & \multirow{2}{*}{ SEM } \\
\hline & A $(0 \%)$ & B $(20 \%)$ & $\mathrm{C}(30 \%)$ & \\
\hline Creatinine $(\mu \mathrm{mol} / \mathrm{L})$ & $111.50^{\mathrm{b}}$ & $117.50^{\mathrm{a}}$ & $113.00^{\mathrm{b}}$ & 1.58 \\
\hline Urea $(\mathrm{mmol} / \mathrm{L})$ & $11.85^{\mathrm{b}}$ & $11.50^{\mathrm{c}}$ & $12.15^{\mathrm{a}}$ & 0.12 \\
\hline Alkaline Phosphatase $(\mu / L)$ & $15.50^{\mathrm{b}}$ & $17.50^{\mathrm{ab}}$ & $18.50^{\mathrm{a}}$ & 0.50 \\
\hline Alanine Aminotransferase $(\mu / \mathrm{L})$ & $4.50^{\mathrm{b}}$ & $6.50^{\mathrm{a}}$ & $5.50^{\mathrm{b}}$ & 0.50 \\
\hline Aspartate Aminotransferase $(\mu / \mathrm{L})$ & $10.50^{\mathrm{b}}$ & $9.50^{\mathrm{b}}$ & $13.50^{\mathrm{a}}$ & 0.50 \\
\hline Calcium (mmol/L) & 1.95 & 2.10 & 2.30 & 0.21 \\
\hline Phosphorus (mmol/L) & 1.03 & 0.93 & 1.15 & 0.11 \\
\hline Total Protein (g/L) & $77.50^{\mathrm{c}}$ & $89.50^{\mathrm{a}}$ & $86.50^{\mathrm{b}}$ & 0.50 \\
\hline Albumin $(\mathrm{g} / \mathrm{L})$ & $41.00^{\mathrm{a}}$ & $35.00^{\mathrm{b}}$ & $40.00^{\mathrm{a}}$ & 1.15 \\
\hline Globulin $(\mathrm{g} / \mathrm{L})$ & $36.50^{\mathrm{b}}$ & $54.50^{\mathrm{a}}$ & $46.50^{\mathrm{a}}$ & 1.50 \\
\hline
\end{tabular}

$\mathrm{a}, \mathrm{b}, \mathrm{c}$, means in the same row with different superscripts are significantly different $(\mathrm{P}<0.05)$.

$\mathrm{A}=0 \%$ sesame residue (control), $\mathrm{B}=20 \%$ sesame residue, $\mathrm{C}=30 \%$ sesame residue, $\mathrm{SEM}=\mathrm{Standard}$ Error of Mean.

\section{CONCLUSION}

In conclusion, white blood cells and red blood cells decreased by 58 and $46 \%$ respectively in lambs fed $30 \%$ inclusion of sesame residue relative to those offered $20 \%$ inclusion level. The normal functioning of the lambs was not impaired by the inclusion levels of the dietary treatments.

\section{ACKNOWLEDGMENT}

The authors would like to thank the Centre for Dryland Agriculture, Bayero University Kano for providing facilities to conduct the research under the Africa Centre of Excellence in Dryland Agriculture project (ACE).

\section{REFERENCES}

[1] Babayemi, O.J., Ekokotu, O.A. and lyang, U.A. (2009). Evaluation of ensiled cassava peels together with Albizia samam pods. In: Proceedings of the $34^{\text {th }}$ Annual Conference of the Nigerian Society of Animal Production, Uyo, Nigeria, pp. 544-546.

[2] Obeidat, B.S. and Aloqaily, B.H. (2010). Using sesame hull in Awassi lambs diets: its effect on growth performance and carcass characteristics and meat quality. Small Ruminant Research, 91:225230. https://doi.org/10.1016/j.smallrumres.2010.03.004.

[3] Obeidat, B.S. and Gharaybeh, F.F. (2011). Effect of feeding sesame hull on growth performance, nutrient digestibility, and carcass characteristics of Black goat kids. Asian-Australasian Journal of
Animal Sciences, https://doi.org/10.5713/ajas.2011.10107.

$24: 206-213$

[4] Ojebiyi, O.O., Farina, G.O., Togun, V.A., Aderinbola, O.A., Olayemi, T.B. and Moronfolu, O.O. (2007). Study on growth and haematological attribute of weaner rabbit ted graded level of sun dried Cassava peel, blood meal mixture. Proceeding of the $32^{\text {nd }}$ annual conference of the Nigerian Society for Animal Production, Calabar, Nigeria.

[5] Gupta, A.R., Putra, R.C., Sani, M. and Swarup, D. (2007). Haematology and serum biochemistry of Chital (Axis axis) and barking deer (Muntiacus muntijax) reared in semi-captivity. Veterinary Research Communications, 31:801-808. https://doi.org/10.1007/s11259-006-0095-8.

[6] KNARDA (2006). Kano Agricultural and Rural Development Authority. Metrological station reports temperature record book and management unit no.11:1-2.

[7] Coles, E.H. (1986). Veterinary Clinical Pathology Manual. $4^{\text {th }}$ ed. Harcourt Brace Jovanarich Inc. Philadelphia: WB Saunders Company, pp. 498-517.

[8] Aiello, S.E. (1998). The Merck Veterinary Manual. $8^{\text {th }}$ ed. Philaldelphia: National Publishing, Inc., pp. 8.

[9] Rej, R., and Hoder, M. (1983). Aspartate transaminase. In: Methods of Enzymatic Analysis. $3^{\text {rd }}$ ed. (H.U. Bergmeyer, J. Bergmeyer, and M. Grassl, Eds.). Weinhein Verlag-Chemie, 3:416-433.

[10] Kohen, R.A. and Allen, M.S. (1995). Enrichment of Proteolitic Activity Relative to Nitrogen in Preparation from the Rumen for in vitro Studies. Animal Feed Science and Technology, 52(1/2):1-14

[11] Peter, T., Biamonte, G.T. and Doumas, B.T. (1982). Protein (total protein) in Serum, Urine and Cerebrospinal Fluids; Albumin in Serum. In: W.R. Paulker, and Meotes, (eds.). Selected Method of Clinical Chemistry. Washington, D.C.: American Association for Clinical Chemistry, pp. 1 -7.

[12] JMP (2007). JMP Version 14. SAS Institute Inc., Cary, NC.

[13] Campbell, J.R., Kenealy, M.D. and Campbell, K.L. (2003). Animal Science. The Biology, Care and Production of Domestic Animals. $4^{\text {th }}$ ed. Boston (Mass.): McGraw-Hill, pp. 179-202. 
[14] RAR (2009). Research Animal Resource. Reference values for laboratory animals: normal haematological values [Internet]. Available from http://www.ahc.umn.edu/rar/refvalues.html.

[15] Bello, A.A. and Tsado, D.N. (2013). Haematological and biochemical profile of growing Yankasa rams fed sorghum stover supplemented with graded levels of dried poultry droppings based diets. Pakistan Journal of Biological Sciences, 16(24): 1922-1928. https://doi.org/10.3923/pjbs.2013.1922.1928.

[16] Reitman, S. and Frankel, S. (1957). Procedure for Analysis of Alanine Amino Transferase and Aspartate Amino Transferase. American Journal of Clinical Pathology, 28:56.

[17] Flegg, H.M. (1973). Determination of Serum Cholesterol by an Enzymatic Method. Annals of Clinical Biochemistry, 10(3): 79-84

[18] Ahamefule, F.O., Obua, B.E., Ukweni, M.A., Oguike, M.A., Amaka, R.A. (2008). Haematological and biochemical profile of weaner rabbits fed raw or processed pigeon pea seed meal based diets. African Journal of Agricultural Research, 3: 315-319. https://doi.org/10.5897/AJAR.9000383.

[19] Saleh, G. and Sanusi, H. (2019). Haematological and Serum Biochemistry Profiles of Yankasa Sheep Fed Complete Diets Containing Rice Straw. American Research Journal of Agriculture, 5(1): 1-7. https:// doi.org/10.21694/2378-9018.19005.

[20] Aster, J.C. (2004). Anaemia of Diminished Erythropoiesis. In: Robbins and Cotran Pathologic Basis of Disease $7^{\text {th }}$ ed. Saunders Co. Philadelphia, pp. 648-649.

[21] Radostits, O.M., Gay, C.C., Hinchcliff, K.W and Constable, P.D. (2007). Veterinary medicine. A text book of the disease of cattle, horses, sheep, pigs and goats. $10^{\text {th }}$ ed Elsevier London, pp. 674-762.

[22] Garba, Y. and Abubakar, A.S. (2012). Haematological Response and Blood Chemistry of Yankasa Rams Fed Graded Levels of Tamarindus indica (Tamarind) Leaves. Nigerian Journal of Basic and Applied Science, 20(1):44-48.

[23] Griss, L.G., Galli, G.M., Marcon, H.J., Baumel, E.A., Souza, C.F., Baldissera, M.D., Vedovatto, M., Sumny, E.H., Kempka, A.P. and Da Silva, A.S. (2020). Effects of yucca extract and organic chromium on growth performance and health of lactating lambs, Small Ruminant Research, 191:

124-27. https://doi.org/10.1016/j.smallrumres.2020.106172.

[24] Njidda, A.A., Shuai'bu, A.A. and Isidahomen, C.E. (2014). Indices of sheep in semi-arid environment of northern Nigeria. Global Journal of Science Frontier Research, 14: 2249-4626.

[25] Bamgbose, A.M., Nwokoro, S.O. and Tewe, O.O. (2003). Serum metabolites and nutrient utilization of boilers fed extruded full fat soya bean diets. Journal of Arid Agriculture, 13: 167-171.

[26] Tripathi, M.K., Mondal, D. and Karim, S.A. (2007). Growth, haematology, blood constituents and immunological status of lambs fed graded levels of animal feed grade damaged wheat as substitute of maize. Journal of Animal Physiology and Animal Nutrition, 92: 7585. https://doi.org/10.1111/j.1439-0396.2007.00712.x.

[27] Gray, C.H. and Howorth, P.J.N. (1980). Clinical Chemical Pathology. 9th ed. London, English Language Book Society and Edward Arnold (publishers) Ltd., pp 91-112.

[28] Banerjee, G.C. (2007). A Textbook of Animal Husbandry. 8th ed Oxford and IBJ publishing Co. PVT Ltd, New Delhi, pp. 1079.

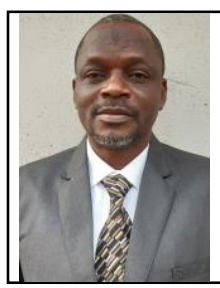

Y. Garba was born in Lagos, Nigeria on 18th June, 1972. Yusuf has a Bachelor of Agriculture (Animal Science) from Usmanu Danfodiyo University, Sokoto, Nigeria (1998), M.Sc. Animal Science from Bayero University, Kano, Nigeria (2010) and $\mathrm{PhD}$ Animal Science from Bayero University, Kano, Nigeria (2014). Area of specialization is ruminant nutrition and management.

He started his job career in the banking sector as a Management Trainee in May, 2000 in the then International Trust Bank Plc. and joined the academia in 2007. He is presently in the services of Bayero University, Kano, Nigeria as a lecturer/researcher and currently an Associate Professor in rank. He has over fourty scientific articles to his credit among which are:

Garba, Y. and Muhammad, I.R. (2008). Sabara (Guiera senegalensis) as Browse and a Potential Milk Enhancer in Ruminants in the Semi-Arid Environment. Research Journal of Animal Sciences, 2 (4):123-127.

Ashiru, R.M., Garba, Y., Maigandi, S.A., and Muhammad, I.R. (2017). Performance of Yankasa Sheep fed Complete Rations Containing Inclusion Levels of Ensiled Sugarcane Waste with Poultry Litter. Iranian Journal of Applied Animal Science (2) 265-269

Garba, Y. and Ibrahim, Z.H. (2019). Haematological and Biochemica Parameters of Kano Brown Bucks fed graded levels of Potash-Treated neem (Azadirachta indica) leaf meal-based diets. Nigerian Journal of
Animal Production 46(1): 196 - 205

His area of research interest is the use of unconventional feed resources in the nutrition of ruminant animals.

Dr Garba is a registered Animal Scientist (RAS) by the Nigerian Institute of Animal Science (NIAS) and member of the Animal Science Association of Nigeria (ASAN), Agricultural Society of Nigeria (ASN) and the Nigerian Society for Animal Production (NSAP). 